\title{
Processes that Affect Electrospray Ionization-Mass Spectrometry of Nucleobases and Nucleosides
}

\author{
Ten-Yang Yen and M. Judith Charles \\ Department of Environmental Sciences and Engineering, University of North Carolina, Chapel Hill, \\ North Carolina, USA \\ Robert D. Voyksner \\ Analytical and Chemical Sciences, Research Triangle Institute, Research Triangle Park, North Carolina, USA
}

\begin{abstract}
Due to the complexity of electrospray ionization processes and the many factors that affect the ion signal, optimization of electrospray ionization methods to gain ultimate sensitivity for analysis of nucleobases and nucleosides may not be straightforward. In this work, we investigated the effect of the $\mathrm{p} K_{a}$ and the gas-phase basicity of analyte and other electrolytes on the $[\mathrm{M}+\mathrm{H}]^{+}$ion signal for 11 select nucleobases and nucleosides in $50 \%$ methanol:water solution. Solution chemistry plays a role in the electrospray signal for all analytes, but gas-phase chemistry may be important for compounds with $\mathrm{p} K_{a}<3$ depending on the solution composition. For compounds with $\mathrm{p} K_{a}<3$, gas-phase proton transfer reactions can be promoted to increase analyte electrospray response by the addition of ammonium acetate to the solution. (C) 1996 American Society for Mass Spectrometry (J Am Soc Mass Spectrom $1996,7,1106-1108)$
\end{abstract}

$\mathrm{T}$ The ion formation processes of electrospray ionization (ESI) are complex. Many parameters and processes of solution equilibrium affect the ion signal [1-17]. Such parameters include characteristics of the analyte and the solution (e.g., the $\mathrm{p} K_{a}$, concentration and surface activity of analyte, the presence of other electrolytes in solution, and the surface tension and dielectric constant of the solvent) [3-17]. These parameters also can influence nonequilibrium processes that involve the formation and enrichment of analyte ions on the surface of liquid droplets, the disruption of larger droplets into smaller offspring droplets, and the desorption of analyte ions from the surface of such droplets into the gas phase [9-11, 14]. The same parameters affect both processes, making it difficult to decipher the specific effect of a variable.

The most abundant ions in the ESI positive ion mass spectra are the $[\mathrm{M}+n \mathrm{H}]^{n+}$ ions for peptides or proteins and the $[\mathrm{M}+\mathrm{H}]^{+}$ions for nucleobases or nucleosides $[1-6,8-13,15-17]$. Compounds with higher $\mathrm{K}_{a}$ generally yield a greater response $[5,17]$. This suggests that the observed $[\mathrm{M}+\mathrm{H}]^{+}$ion signal is related to the concentration of the protonated analyte in solution. Attempts to enhance the $[\mathrm{M}+\mathrm{H}]^{+}$ion signal by adjusting the solution $\mathrm{pH}$ brings its own problems $[5,6$, 9-13]. In solutions acidified with strong acids a rapid reduction in the signal occurs due to charge neutralization between the protonated analyte and the anion of

Address reprint requests to Dr. M. Judith Charles, Department of Environmental Toxicology, University of California, Davis, CA 95616. the strong acid (ion-pair interactions) [12, 13]. In fact, because of nonequilibrium processes such as electrophoretic charging, droplet disruption, and evaporation, the actual $\mathrm{pH}$ under which desorption occurs can be greatly different from the $\mathrm{pH}$ in bulk solution [9-11]. Ion suppression also occurs when other electrolytes $\left(>10^{-6} \mathrm{M}\right)$ are present in solution $[3,4,8-13]$. The degree of signal reduction is dependent on the concentration and the surface activity of the analytes and the electrolytes $[3,4]$. In addition, gas-phase proton transfer reactions between neutral molecules and protonated ions can occur. Such interactions increase the complexity of optimization protocol $[5,15,16]$.

To date few studies exist that investigate the relative importance and balance among processes that occur in the solution or in the gas phase. A greater study of these processes is thus justified and needed to gain practical knowledge about approaches to optimize ESI methods. Herein, we conduct such a study to investigate the influence of the $\mathrm{pK}_{a}$ and the gas-phase basicity of analyte and other electrolytes on the [M+ $\mathrm{H}^{+}$ion intensity of selected nucleobases and nucleosides.

\section{Experimental}

\section{Standards and Samples Preparation}

Nucleobases and nucleosides (free base) were purchased from Sigma Chemical Co. (St. Louis, MO) or 
Aldrich Chemical Co. (Milwaukee, WI). Water and methanol (high-performance liquid chromatography grade) were obtained from Fisher Scientific (Fair Lawn, NJ) and Mallinckrodt (Paris, KY), respectively. Tripropylamine (free base) and ammonium acetate were bought from Aldrich Chemical Co. and EM Science (Gibbstown, NJ), respectively. Solutions of nucleobases and nucleosides were prepared in 50\% methanol:water ( $\left.\mathrm{MeOH}: \mathrm{H}_{2} \mathrm{O} v / v\right)$ and were stored in polypropylene plastic containers. In order to avoid acidification due to dissolution of $\mathrm{CO}_{2}$ in solution, we degassed samples by passing a stream of He through the sample solution for $30 \mathrm{~min}$ prior to the analysis by electrospray ionization-mass spectrometry (ESI-MS).

\section{Instrumental Conditions}

The experiments were conducted on a Finnigan 4000 quadrupole mass spectrometer (Finnigan-MAT, San Jose, CA) equipped with an ESI source (nonpneumatically assisted electrospray ionization) obtained from Analytica of Branford (Branford, CT). Details of this ESI source design are presented elsewhere [18]. The voltage on the electrospray needle was set to maximize the $[\mathrm{M}+\mathrm{H}]^{+}$signal $(3.0-3.9 \mathrm{kV})$. We set the voltage difference between the exit of the glass capillary and the first skimmer at $70-80 \mathrm{~V}$ to optimize the analyte signal and to minimize the fragmentation due to collision-induced dissociations in this differential pumping region. The flow rate of the solution was controlled by using a syringe pump (Sage 341B, Sage Instruments, Boston, MA) at $2 \mu \mathrm{L} / \mathrm{min}$. Mass spectra were acquired and processed by a Technivent Vector/2 (St. Louis, MO) data system over a mass range from $m / z 20$ to 400 in $1 \mathrm{~s}$. The relative intensity of the $[\mathrm{M}+\mathrm{H}]^{+}$ion was determined by the average of 60 scans and was normalized to that of thymine. We ensured continuity of the data among analyses conducted in one day and on different days by analyzing 5- $\mu \mathrm{M}$ standards of thymine, Overall, the variability within a day and among days was $<15 \%$.

\section{Results and Discussion}

To study the influence of $\mathrm{p} K_{a}$ and gas-phase proton transfer reactions on the electrospray response of nucleobases and nucleosides, we investigated the effect of ammonium acetate and tripropylamine (TPA) in solution on the $[\mathrm{M}+\mathrm{H}]^{+}$ion signal of thymine, guanine, and adenine. The employment of such solutions provides for an elegant experiment because the $\mathrm{p} K_{a}$ of $\mathrm{NH}_{3}\left(\mathrm{p} K_{a}=9.3\right)$ and TPA $\left(\mathrm{p} K_{a}=10.4\right)$ are both higher than those of adenine $\left(\mathrm{p} K_{a}=4.1\right)$, guanine $\left(\mathrm{p} K_{a}=3.2\right)$, and thymine $\left(\mathrm{p} K_{a}=0\right)$, and the gas-phase basicity of $\mathrm{NH}_{3}(\mathrm{~GB}=195.6 \mathrm{kcal} / \mathrm{mol})$, but not TPA $(\mathrm{GB}=226.2$ $\mathrm{kcal} / \mathrm{mol}$ ), is lower than those of adenine ( $\mathrm{GB}=215.7$ $\mathrm{kcal} / \mathrm{mol}$ ), guanine (GB $=215 \mathrm{kcal} / \mathrm{mol}$ ), and thymine $(\mathrm{GB}=201 \mathrm{kcal} / \mathrm{mol})[5,19-22]$. This combination of physicochemical characteristics means that (1) it is not possible for a proton from $\mathrm{NH}_{4}^{+}$or $[\mathrm{TPA}+\mathrm{H}]^{+}$to be transferred to the analyte in solution and (2) gas-phase proton transfer can occur by transfer of a proton from $\mathrm{NH}_{4}^{+}$to adenine, guanine, and thymine, but not by transfer of a proton from $[\mathrm{TPA}+\mathrm{H}]^{+}[5,20]$. Thus, if gas-phase proton transfer is an important process, then an increase in the ion signal with increasing concentrations of ammonium acetate will be observed.

We present the data in Figure 1 as a plot of the relative intensity of the $[\mathrm{M}+\mathrm{H}]^{+}$ion versus concentration of ammonium acetate and TPA. The $[\mathrm{M}+\mathrm{H}]^{+}$ ion intensities for adenine and guanine exhibit a linear decrease with increasing concentrations of ammonium acetate. This signal reduction is due to the presence of high concentrations of electrolytes in solution. For thymine, we observe an initial increase in the intensity of $[\mathrm{M}+\mathrm{H}]^{+}$from 5 to $500 \mu \mathrm{M}$ of $\mathrm{CH}_{3} \mathrm{COONH}_{4}$ and then a slight decrease at a concentration of $0.005 \mathrm{M}$. This initial increase in the ion signal supports the notion that gas-phase protonation results in the formation of $[\mathrm{M}+\mathrm{H}]^{+}$from the reaction $[\mathrm{B}+\mathrm{H}]^{+}+\mathrm{M} \rightleftarrows$ $\mathrm{B}+[\mathrm{M}+\mathrm{H}]^{+}$, where $\mathrm{M}$ is the neutral thymine molecule and $\mathrm{B}$ is $\mathrm{NH}_{3}$.

For TPA, we observe a rapid decrease in the intensity of the $[\mathrm{M}+\mathrm{H}]^{+}$ion for adenine, guanine, and thymine with increasing TPA concentration. Whereas TPA has a higher gas-phase basicity than the compounds investigated, the $[\mathrm{M}+\mathrm{H}]^{+}$ions cannot be promoted by gas-phase proton transfer reactions. This sharp decrease in the ion signal with TPA likely is due to the competition for protons in either the gas or condensed phase [3, 4].

The relationship between the $\mathrm{p} K_{a}$ of analyte and the influence of the presence of ammonium acetate in solutions is further exemplified by the results shown in Figure 2. In this figure, we present a plot of the intensity of $[\mathrm{M}+\mathrm{H}]^{+}$ions of 11 nucleobases and nucleosides $(50 \mu \mathrm{M})$ in a solution that contains $500-\mu \mathrm{M}$ ammonium acetate and in a solution without ammonium acetate, versus the analyte $\mathrm{p} K_{a}$. These data indi-

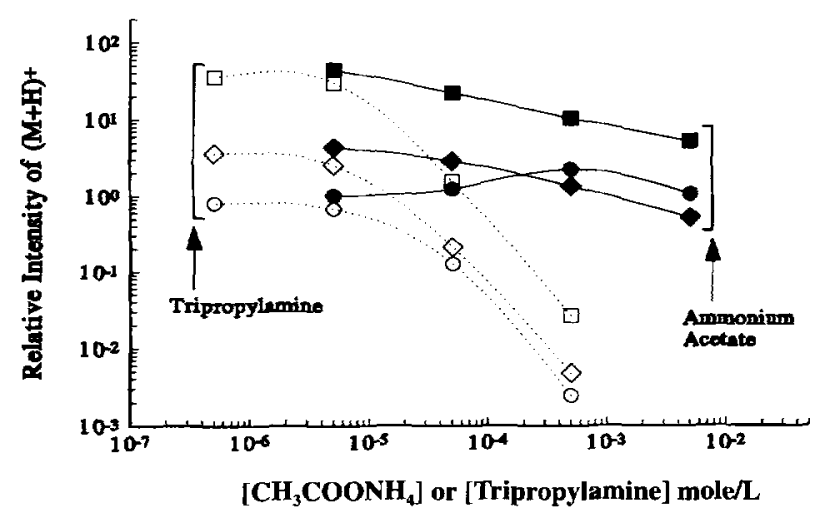

Figure 1. Effect of the concentration of ammonium acetate (solid points) and tripropylamine (open points) on the intensity of the $[\mathrm{M}+\mathrm{H}]^{+}$ion for $5-\mu \mathrm{M}$ solutions of adenine $(\boldsymbol{\square}, \square)$, guanine $(\diamond, \diamond)$, and thymine $(\bullet, 0)$. 


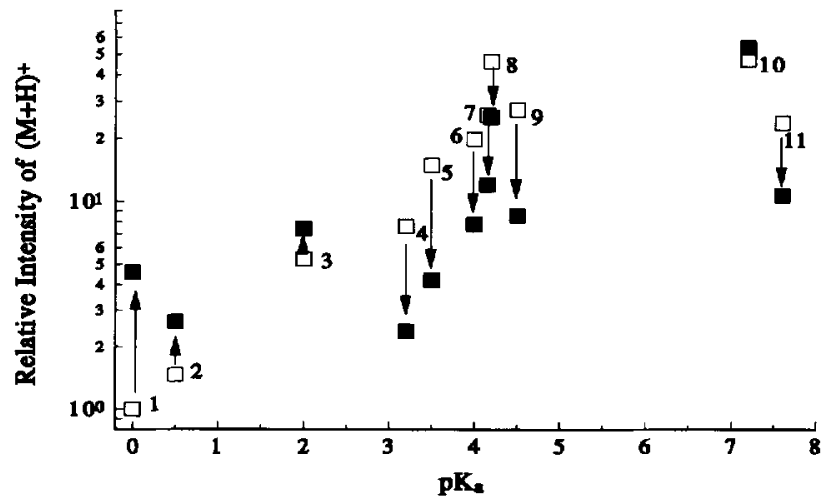

Figure 2. Plot of the intensity of the $[\mathrm{M}+\mathrm{H}]^{+}$ion versus the $\mathrm{p} K_{a}$ of the analyte. The arrow indicates the direction of change in the intensity of the $[\mathrm{M}+\mathrm{H}]^{+}$ion signal from solution without ammonium acetate ( $\square$ ), to solution with $500-\mu \mathrm{M}$ ammonium acetate ( $\square)$. The compounds are (1) thymine $(\mathrm{p} K=0.0)$, (2) uracil $\left(\mathrm{p} K_{a}=0.5\right)$, (3) hypoxanthine $\left(\mathrm{p} K_{a}=2.0\right)$, (4) guanine $\left(\mathrm{p} K_{a}=3.2\right)$, (5) 7-methylguanine $\left(\mathrm{p} K_{a}=3.5\right)$, (6) $N^{6}$-methyladenosine $\left(\mathrm{p} K_{a}=4.0\right)$, (7) adenine $\left(\mathrm{p} K_{a}=4.1\right)$, (8) $N^{6}$-methyladenine $\left(\mathrm{p} K_{a}=4.2\right)$, (9) cytosine $\left(\mathrm{p} K_{a}=4.5\right)$, (10) 1-methyladenine ( $\left.\mathrm{p} K_{a}=7.2\right)$, (11) 1-methyladenosine $\left(\mathrm{p} K_{a}=7.6\right)$.

cate that for solutions without ammonium acetate, the intensity of $[\mathrm{M}+\mathrm{H}]^{+}$ions for compounds with $0 \leq$ $\mathrm{p} K_{a} \leq 4$ is proportional to their $\mathrm{p} K_{a}$. For compounds with $\mathrm{p} K_{a}>4$, the intensity of the $[\mathrm{M}+\mathrm{H}]^{+}$ion signal reaches a plateau, which suggests that the actual $\mathrm{pH}$ of liquid droplets of $50 \%$ methanol:water solutions upon ion desorption is $\leq 4$. Furthermore, for compounds with $\mathrm{p} K_{a}<3$, the $[\mathrm{M}+\mathrm{H}]^{+}$ion signal increases with the presence of ammonium acetate (solid square points, a) in comparison with those in solution without added ammonium acetate (open square points, $\square$ ). In contrast, a decreasing trend is observed for compounds with $\mathrm{p} K_{a}>3$ in ammonium acetate solution. Gasphase proton transfer reactions thus play an important role in the electrospray ionization of compounds with $\mathrm{p} K_{a}<3$. Compounds with higher $\mathrm{p} K_{a}$, however, are not significantly affected by gas-phase proton transfer reactions.

\section{Conclusion}

Optimization of the electrospray response of nucle obases and nucleosides is a challenge due to the many processes and parameters that must be considered. We have demonstrated that solution chemistry affects the signal for all analytes, but gas-phase proton transfer chemistry may be important for compounds with $p K_{a}<3$. The relative significance of such processes depends on the $\mathrm{p} K_{a}$ and the gas-phase basicity of the analytes, and the nature of electrolyte in solution. It is acknowledged also that because the analyte's gas basicity is unknown, in certain cases such as 1-methyladenosine, the $\mathrm{p} K_{a}$ and gas basicity may not be perfectly correlated. For compounds with $\mathrm{p} K_{a}<3$, the addition of ammonium salts $(0.5 \mathrm{mM})$ can promote gas-phase proton transfer reactions to increase the [M $+\mathrm{H}]^{+}$ion intensity (although negative ion ESI-MS may be more suitable in such cases).

\section{Acknowledgments}

This research was supported in part by a grant from NIEHS (P42 ES05948). We thank Dr. Thomas N. Feinberg for helpful discussions and we appreciate the valuable suggestions by the reviewers. We also thank Dr. Craig M. Whitehouse of Analytica of Branford, Inc., for his assistance with the ESI source.

\section{References}

1. Fenn, J. B.; Mann, M.; Meng, C.-K.; Wong, S. F.; Whitehouse, C. M. Mass Spectrom. Rev. 1990, 9, 37-70.

2. Smith, R. D.; Loo, J. A.; Ogorzalek Loo, R. R.; Bushman, M.; Udseth, H. R. Mass Spectrom. Rev. 1991, 10, 359-451.

3. Fenn, J. B. J. Am. Soc. Mass Spectrom. 1993, 4, 524-535.

4. Kebarle, P.; Tang, L. Anal. Chem. 1993, 65, 972A-986A.

5. Ikonomou, M. G.; Blades, A. T.; Kebarle, P. Anal. Chem. 1990, 62, 957-967.

6. Hiraoka, H.; Kudaka, I. Anal. Chem. 1992, 64, 75-81.

7. Tang, L.; Kebarle, P. Anal. Chem. 1991, 63, 2709-2715.

8. Tang, L.; Kebarle, P. Anal. Chem. 1993, 65, 3654-3688.

9. Kelly, M. A.; Vestling, M. M.; Fenselau, C. C.; Smith, P. B. Org. Mass Spectrom. 1992, 27, 1143-1147.

10. Gatlin, C. L.; Tureček, F. Anal. Chem. 1994, 64, 712-718.

11. Wang, G.; Cole, R. B. Org. Mass Spectrom. 1994, 29, 419-427.

12. Mirza, U. A.; Chait, B. T. Anal. Chem. 1994, 66, 2898-2904.

13. Kuhlmann, F. E.; Apffel, A.; Fischer, S. M.; Goldberg, G.; Goodley, P. G. J. Am. Soc. Mass Spectrom. 1995, 6, 1221-1225.

14. Rosell-Llompart, J.; Fernández de la Mora, J. J. Aerosol. Sci. 1994, 25, 1093-1119.

15. McLuckey, S. A.; Van Berkel, G. J.; Glish, G. L. J. Am. Chem. Soc. 1990, 112, 5668-5670.

16. Ogorzalek Loo, R. R.; Smith, R. D. J. Am. Soc. Mass Spectrom. 1994, 5, 207-220.

17. Banks, J. F.; Shen, S.; Whitehouse, C. M.; Fenn, J. B. Anal. Chem. 1994, 66, 406-414.

18. Straub, R. F.; Voyksner, R. D. J. Am. Soc. Mass Spectrom. 1994, 4, 578-587.

19. Lias, S. G.; Liebman, J. F.; Levin, R. D. I. Phys. Chem. Ref. Data 1984, 13, 695.

20. Bursey, M. M.; Parker, C. E.; Smith, R. W.; Gaskell, S. J. Anal. Chem. 1985, 57, 2597--2599.

21. Dawson, R. M. C.; Elliott, D. C.; Elliott, W. H.; Jones, K. M. Eds. Data for Biochemical Research; Oxford University Press: New York, 1959; pp 66-81.

22. Krstulović, A. M., Ed. CRC Handbook of Chromatography: Nucleic Acids and Related Compounds.; CRC Press: Boca Raton, FL, 1987. 